\title{
Redox homeostasis of albumin in relation to alpha-lipoic acid and dihydrolipoic acid
}

\author{
Pinar Atukeren, ${ }^{1}$ Seval Aydin, ${ }^{1}$ Ezel Uslu, ${ }^{1}$ M.Koray Gumustas and Ufuk Cakatay, ${ }^{2, *}$ \\ 'Cerrahpasa Medical Faculty; Department of Biochemistry; ${ }^{2}$ Istanbul Faculty of Medicine, Central Laboratory of Clinical Biochemistry; Istanbul University; Istanbul, Turkey
}

Key words: albumin, lipoic acid, oxidative stress, protein oxidation

\begin{abstract}
Albumin represents the predominant circulating antioxidant agent in plasma exposed to continuous oxidative stress and a change in serum albumin structure accounts for its antioxidant properties. Alterations in the redox status of albumin may result in impairments of its biological properties. Alpha-lipoic acid (LA), a naturally occurring thiol compound found in virtually all species, is a potent antioxidant with high efficacy which is also involved in the chelation of metal ions, regeneration of antioxidants, and repair of oxidatively damaged proteins. In human body LA is rapidly reduced to dihydrolipoic acid (DHLA) after intake into the cell. Both, LA and DHLA are amphipathic molecules which act as antioxidants both in hydrophilic and lipophilic environments. The present study aimed to investigate the antioxidant/ pro-oxidant effects of LA and DHLA due to their concentrations in metal-catalyzed protein oxidation (MCO) of human serum albumin (HSA). Progressive oxidative modification of albumin was found in MCO system by an increased content of protein hydroperoxides (POOH), protein carbonyl groups (PCO) which is the former's major breakdown product, and other protein oxidation markers such as advanced oxidized protein products (AOPP) and protein thiol groups (P-SH). The possible antioxidant protective effects of LA and DHLA were observed with $25 \mu \mathrm{M}$ and $50 \mu \mathrm{M}$; DHLA being more influential. Protein oxidation parameters were found to be lower and P-SH levels seemed higher. However, prooxidant effects of both LA and DHLA came on the scene with increased concentrations of $75 \mu \mathrm{M}$ and $100 \mu \mathrm{M}$ where the latter seemed the most hazardous with contradicted results. It is clear that the loss of biological activity of human serum albumin by MCO system appears of medical relevance and if LA exerts similar effects seen in the present study, it is possible that cellular prooxidant activity can also result consuming this unique antioxidant in certain doses.
\end{abstract}

\section{Introduction}

The regulation of plasma osmotic pressure, the binding and transport of endogenous and exogenous compounds, and antioxidant functions comprise a set of quite diverse functions. ${ }^{1} \mathrm{~A}$ single molecule is involved in all of these bio-functions: albumin. Most of the antioxidant properties of albumin can be attributed to its three-dimensional structure and it has previously shown that all these properties could be partially impaired by reactive oxygen species (ROS)..$^{1-5}$ Oxidative stress is believed to play a pathophysiological role in a variety of disease and it is readily conceivable that the ligand binding properties of albumin may be altered during the development of these pathologies. Albumin exists in both reduced and oxidized forms in systemic circulation. The reduced form of the human serum albumin (HSA) has been shown to be lower in patients with hepatic disorders, diabetes, and renal diseases. ${ }^{4-5}$

HSA $(66.5 \mathrm{kDa})$, a single chain of 585 amino acids, is the most abundant plasma protein in plasma, typically present at high concentrations $(\sim 0.6 \mathrm{mM}))^{5-7}$ Therefore, ROS and products of their reactions with other macromolecules occur physiologically and pathophysiologically in the vicinity of albumin. It consists of three structurally homologous, largely helical (67\%) domains I, II, and III. Each domain consists of two sub-domains, A and B. Like other mammalian albumins, HSA contains 17 disulfide bridges and free thiol (sulphydryl) group at Cys-34.5.7 It is clear from previous publications that HSA has a variety of metal-binding sites with different specificity. ${ }^{1,6}$ The binding properties of HSA depend on the three dimensional structure of the binding sites, which are distributed over the albumin molecule. ${ }^{1}$ Domain II in HSA is the preferred site for binding as fatty acids and alpha-lipoic acid (LA) share structural similarity to the medium chain fatty acid, octanoic acid ${ }^{7}$ and this mechanism is shown in Figure 1.

Although LA and other antioxidant supplements are widely used by the public and can prove beneficial in some patient groups, there remains a lack of detailed knowledge on its extracellular protective effects under different specific physiological circumstances. LA (1,2-dithiolane-3-pentanoic acid) is a sulfur-containing antioxidant with metal-chelating and antiglycation capabilities. Unlike many antioxidants which are active only in lipid or aqueous phase, LA is active in both lipid and 


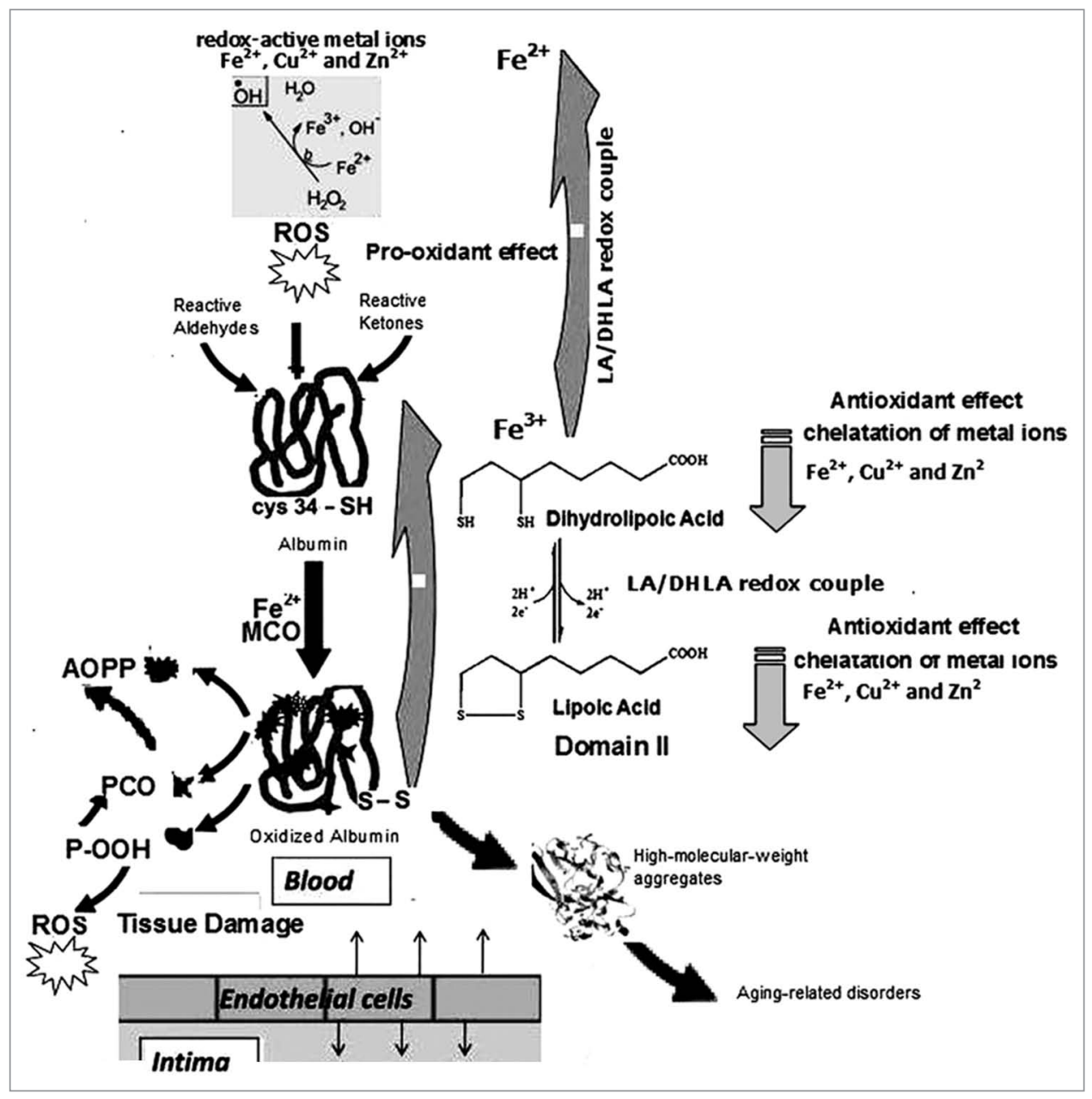

Figure 1. Metal ion-catalyzed albumin oxidation, alpha-lipoic acid, and intravascular redox homeostasis. ROS, reactive oxygen species; $M C O$, metalcatalyzed protein oxidation; LA, alpha-lipoic acid; DHLA, dihydrolipoic acid; POOH, protein hydroperoxides; PCO, protein carbonyl groups; AOPP, advanced oxidation protein products.

aqueous phases. LA is part of a redox pair, being the oxidized partner of the reduced form dihydrolipoic acid (DHLA). Due to an asymmetric carbon having four different attached groups, LA exists as two enantiomers: the (R)-enantiomer and the (S)-enantiomer. Naturally-occurring LA is the (R)-form, but synthetic LA is a racemic mixture of (R)-form and (S)-form. ${ }^{8}$ Although the $(\mathrm{R})$-enantiomer is more biologically active than the (S)-enantiomer, administration of LA actually results in greater formation of DHLA due to a synergistic effect which each enantiomer exerts on the reduction of the other. ${ }^{8,9}$ On the other hand, LA and DHLA have been reported to exhibit metalchelating properties and the use of LA to remove metal ions in vivo has been proposed previously. ${ }^{10,11}$ Structurally, the two thiol groups and the carboxyl group of the LA allow binding of various divalent metals. ${ }^{12,13}$ Such chelation by LA appears to be effective in slowing iron- or copper-mediated oxidation of lipids $s^{13}$ or increase in oxidative protein damage $e^{10,11,14,15}$ in various biological model systems (Fig. 1).

Most of the information concerning antioxidant or pro-oxidant effects of LA is available in current literature. ${ }^{8,9,12,14,15}$ However, information concerning the effectiveness of LA and DHLA to prevent in vitro metal-catalyzed protein oxidation (MCO) of HSA does not appear to be available of the relevant literature. The aims of the current study were to examine and compare the effectiveness of LA and DHLA to prevent to MCO of HSA, and to investigate this effect as a function of its concentration.

\section{Results}

The declining kinetics in the absorbtion of MCO buffer for 15 minutes at $265 \mathrm{~nm}$ is seen in Figure 2. When HSA was added to the oxidation mixture, it was observed that it slowed down the MCO reaction mildly in this time interval and compared in the same figure.

Variations in the levels of protein oxidation markers are shown in Figures 3, 4 and 5, respectively. Evidently, oxidation of HSA is observed under these conditions; $\mathrm{POOH}, \mathrm{PCO}$ and $\mathrm{AOOP}$ levels were increased when HSA was exposed to MCO without any antioxidant maintenance significantly. In the inspection of LA and DHLA effects due to their concentration in the reaction 


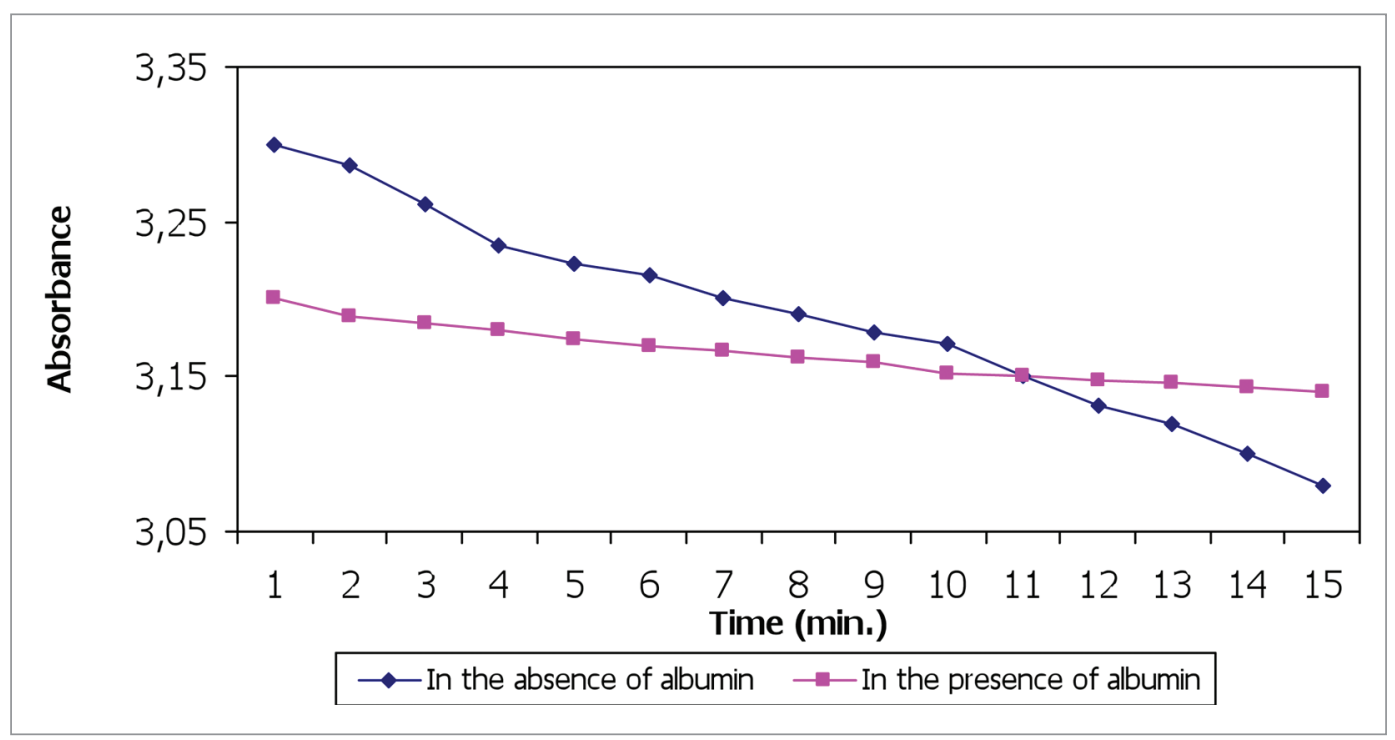

Figure 2. The absorption spectra of in vitro metal catalyzed oxidation system at $265 \mathrm{~nm}$ (A) before and (B) following the albumin treatment.

medium, decreasing PCO and POOH levels were observed when $25 \mu \mathrm{M}$ and $50 \mu \mathrm{M}$ LA and DHLA were used independently (Figs. 3 and 4), but both $\mathrm{PCO}$ and $\mathrm{POOH}$ levels showed increase subsequently when $75 \mu \mathrm{M}$ LA and DHLA were used. There was no significant difference when $\mathrm{PCO}$ and $\mathrm{POOH}$ levels of $25 \mu \mathrm{M}$ and $50 \mu \mathrm{M}$ LA were compared ( $>0.05, \mathrm{p}>$ $0.05)$, so was when the levels of $25 \mu \mathrm{M}$ and $50 \mu \mathrm{M}$ DHLA were compared respectively $(\mathrm{p}>0.05, \mathrm{p}<0.05)$. When $100 \mu \mathrm{M}$ LA and DHLA applied, the increment seen in PCO an $\mathrm{POOH}$ levels was striking and even there was no significant difference when POOH levels of $100 \mu \mathrm{M}$ LA group were compared with the group deprived of LA or DHLA $(p>0,05)$. In Figure 5; AOPP levels are given which were quite amicable with PCO and POOH levels when both LA and DHLA were discussed. Along with $25 \mu \mathrm{M}$ and $50 \mu \mathrm{M}$ of LA and DHLA; AOPP levels declined consecutively but an elevation was seen when LA and DHLA concentrations rised to $75 \mu \mathrm{M}$ and it was striking with $100 \mu \mathrm{M}$ concentration. Both $100 \mu \mathrm{M}$ LA and DHLA administration showed no significant difference when AOPP levels were compared with the group comprising no LA or DHLA ( $p>0.05$ for both parameters). When each applied concentration of LA and DHLA were compared amongst; DHLA indicated statistically lower PCO levels with 25,50 and $75 \mu \mathrm{M}$ concentrations when compared with the same LA concentrations $(\mathrm{p}<0.001$, $\mathrm{p}<0.001, \mathrm{p}<0.001)$ respectively. There was no significant difference when PCO levels of $100 \mu \mathrm{M}$ DHLA and LA were compared $(\mathrm{p}>0.05)$. With POOH levels; the only significant difference was seen when $25 \mu \mathrm{M}$ DHLA and LA concentrations were compared $(\mathrm{p}<0.001)$, DHLA caused lower POOH levels than that of LA. When AOPP levels were evaluated considering comparison within the same concentrations of LA and DHLA; $50 \mu \mathrm{M}$ and $100 \mu \mathrm{M}$ applied DHLA showed lower AOPP formation than same concentrations of LA ( $<0.001, \mathrm{p}<0.001)$ respectively.

The varations in the levels of P-SH groups are seen in Figure 6. Both LA and DHLA administration showed increase with
$25 \mu \mathrm{M}$ and $50 \mu \mathrm{M}$ concentrations when compared with the absence of LA or DHLA. $75 \mu \mathrm{M}$ LA and DHLA lowered the levels and the decrease was obvious with $100 \mu \mathrm{M}$ LA and DHLA, even no significant difference was seen when compared with the absence of LA or DHLA ( $p>0.05, p>0.05$ ) respectively. Statistically 25, 50 and $75 \mu \mathrm{M}$ of DHLA showed more effective on P-SH levels when compared within same concentrations of LA ( $p<0.001$, $\mathrm{p}<0.001, \mathrm{p}<0.001)$. No significant difference was observed when $100 \mu \mathrm{M}$ DHLA and LA were compared $(\mathrm{p}>0.05)$.

\section{Discussion}

Proteins make up the majority of biomolecules in cells and plasma and therefore are the most likely reactants with ROS. Oxidative damage by free radicals in biological systems is often linked to the Fenton reaction. The Fenton reaction is the one electron reduction of hydrogen peroxide $\left(\mathrm{H}_{2} \mathrm{O}_{2}\right)$ by the transition metal ions such as iron and copper. The Fenton reaction is also another way of producing free radicals in experimental settings. In vivo and in vitro, HSA may be oxidatively modified in different ways with different agents at different sites. ${ }^{1,6,7}$ The redox status of HSA can affect its binding properties in several ways, including altered conformation and consequently altered binding affinities at ligand-binding sites. On the other hand the ligandbinding reaction itself is redox sensitive. ${ }^{1}$ The functional alteration of oxidized HSA may have important clinical implications in critical conditions associated with high levels of oxidative stress. ${ }^{16}$ Recent studies on HSA exposed to ROS have employed experimental conditions that cause extensive molecular alterations like aggregation or fragmentation of the molecule. ${ }^{17,18}$

Oxidation of HSA was investigated by using different oxidant systems in vitro studies; the water-soluble azo-initiator 2,2'azobis-(2-amidinopropane) hydrochloride (AAPH), a combination of $\mathrm{FeCl}_{3}$ and ascorbate or the Fenton oxidant consisting of $\mathrm{FeCl}_{2}, \mathrm{H}_{2} \mathrm{O}_{2}$ and EDTA, ${ }^{19}$ chloramine- $\mathrm{T}$ (a hypochloride analogue), ${ }^{20}$ hypochlorus acid, ${ }^{21}$ and even malondialdehyde ${ }^{22}$ and 

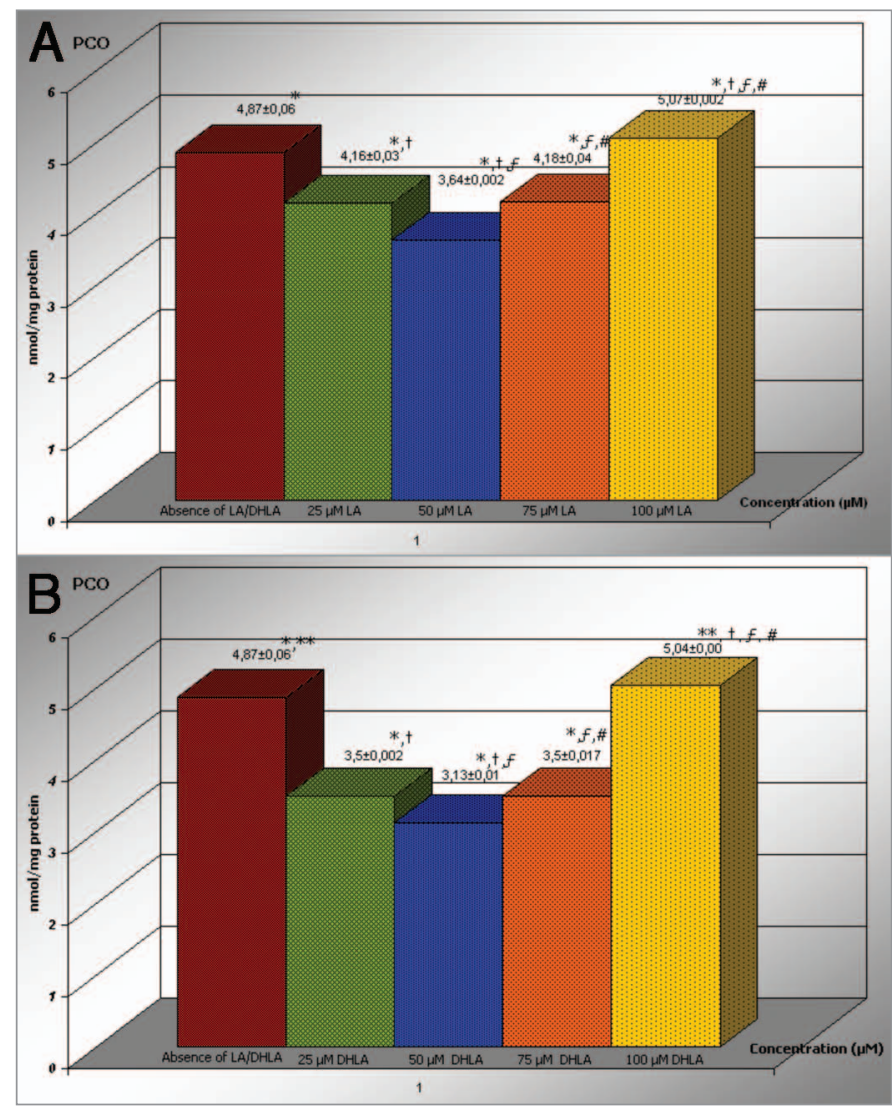

Figure 3. (A) Variations of protein carbonyl groups (PCO) in albumin molecule exposed to metal catalyzed oxidation (MCO) with respect to incremental lipoic acid (LA) concentrations. Results are expressed as mean \pm S.E.M. PCO levels were expressed as $\mathrm{nmol} / \mathrm{mg}$ protein. Data are statistically significant at ${ }^{*}, t, f, \# p<0.001$. (B) Variations of protein carbonyl groups (PCO) in albumin molecule exposed to metal catalyzed oxidation (MCO) with respect to incremental dihydolipoic acid (DHLA) concentrations. Results are expressed as mean \pm S.E.M. PCO levels were expressed as $\mathrm{nmol} / \mathrm{mg}$ protein. Data are statistically significant at ${ }^{*},+, f, \# p<0.001$ and $^{* *} p<0.01$ respectively.

conformational and functional changes were investigated via MCO of HSA in different studies. ${ }^{19,23}$ MCO system is assumed to attack metal binding sites on proteins yielding site specific oxidative modifications. In this study, we have investigated the action of a MCO system on HSA and the antioxidant/pro-oxidant effects of LA and DHLA due to function of their concentrations. The logical reasoning why we have chosen MCO of HSA is; besides the regulation of the plasma osmotic pressure, HSA binds and transports transition metal ions such as bile pigments, mediumchain fatty acids LA and other lipophilic compounds ${ }^{7,24-26}$ and is a known target of in vivo MCO. ${ }^{27}$ The concentration of iron used in our MCO system similar with the plasma concentrations of these redox-active metal ions; $\mathrm{Fe}^{2+}, \mathrm{Cu}^{2+}$ and $\mathrm{Zn}^{2+}$ in vivo ${ }^{28}$ to confirm prediction based on in vitro models.

ROS scavenging by the cellular and plasma proteins result in the formation of reactive $\mathrm{P}-\mathrm{OOH} .^{29,40} \mathrm{P}-\mathrm{OOH}$ are major intermediates in radical-mediated protein oxidation reactions and form stable PCO groups. ${ }^{29,40}$ It is well established that the P-OOHs formed particularly on aliphatic amino acid residues (Val, Leu,
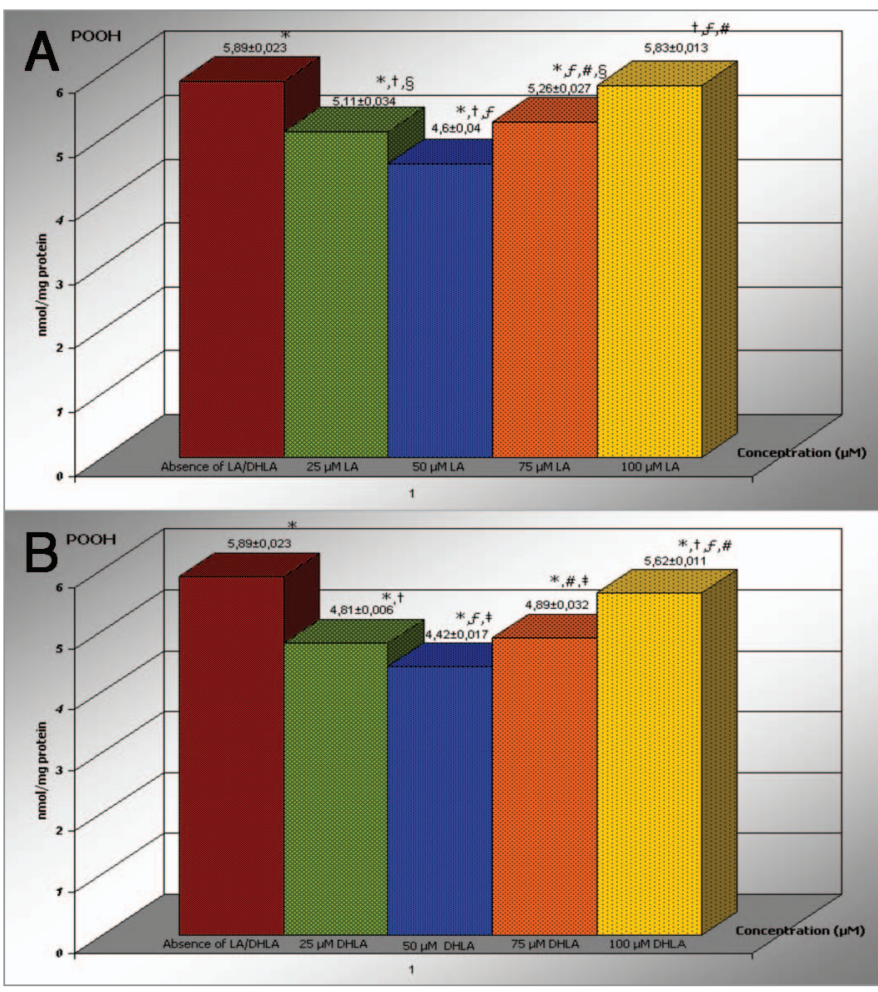

Figure 4. (A) Variations of protein hydroperoxides $(\mathrm{POOH})$ in albumin molecule exposed to metal catalyzed oxidation (MCO) with respect to incremental lipoic acid (LA) concentrations. Results are expressed as mean \pm S.E.M. POOH levels were expressed as $\mathrm{nmol} / \mathrm{mg}$ protein. Data are statistically significant at ${ }^{*}, t, f, \# p<0.001$ and ${ }^{* *}, \S p<0.01$ respectively. (B) Variations of protein hydroperoxides $(\mathrm{POOH})$ in albumin molecule exposed to metal catalyzed oxidation (MCO) with respect to incremental dihydrolipoic acid (DHLA) concentrations. Results are expressed as mean \pm S.E.M. POOH levels were expressed as $\mathrm{nmol} / \mathrm{mg}$ protein. Data are statistically significant at ${ }^{*}, t, f, \# p<0.001$ and $\neq p<0.01$ respectively.

Ile, Glu, Pro, Lys) are generated under the absolute requirement of the presence of oxygen. The P-OOHs may be reductively detoxified to hydroxides but their decomposition products can also result in the formation of further radicals that may propagate reaction chains. Catabolism of oxidised proteins including those containing hydroperoxides, would be expected to result in an increased extent of accumulation of modified proteins in plasma, with this potentially having deleterious consequences for cellular function. ${ }^{33,40}$ AOPP are the proteins, predominantly HSA and its aggregates damaged by oxidative stress. ${ }^{30}$ Albumin comprises the largest thiol pool in plasma. However, other thiol containing compounds with a low molecular weight exist. Albumin contains a total of 35 cysteine residues. Thirty-four of these are involved in intramolecular disulphide bonds while cysteine34 (cys34) remains free. In plasma, there exist several thiol/disulphide couples, including the Cys34 of albumin. In healthy adults, about $70-80 \%$ of the Cys34 in albumin contains a free thiol group; $25 \%$ of the Cys34 forms a disulphide with small thiol compounds like another cysteine, homocysteine or glutathione. ${ }^{1}$ The extracellular redox potential of the cysteine/cystine redox couple was reported to be kept constant and important for regulation of 

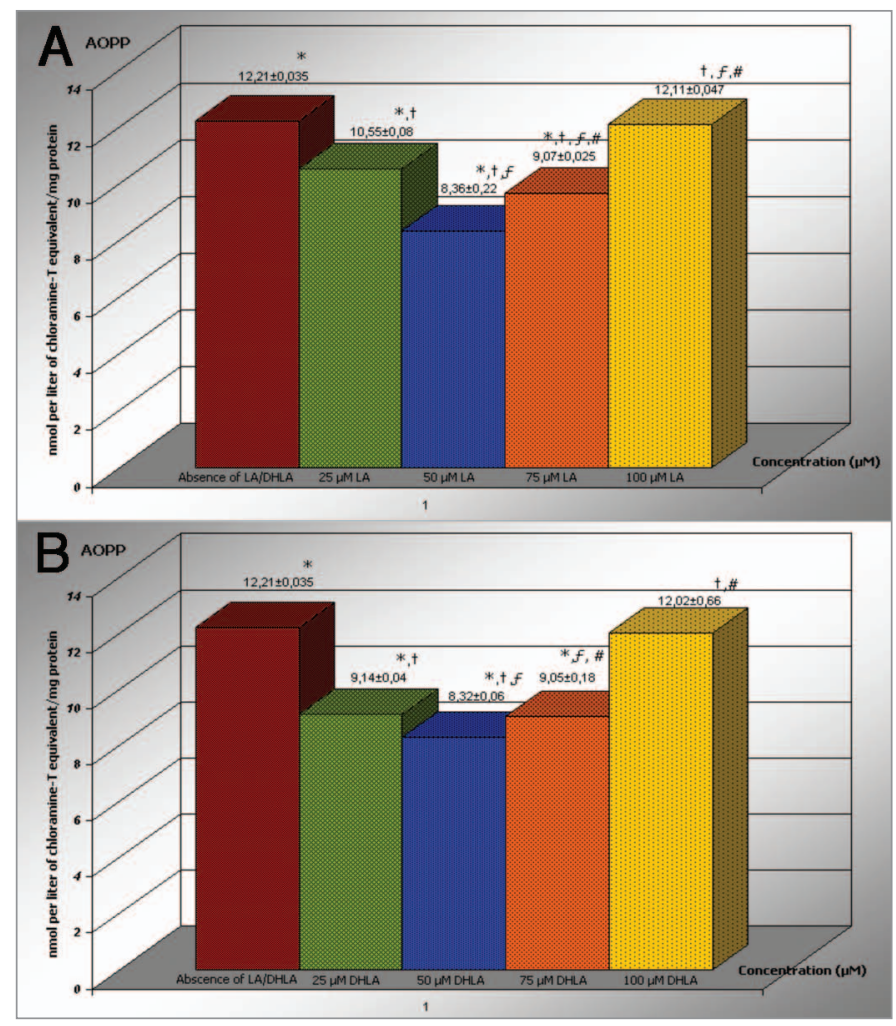

Figure 5. (A) Variations of advanced oxidation protein products (AOPP) in albumin molecule exposed to metal catalyzed oxidation (MCO) with respect to incremental lipoic acid (LA) concentrations. Results are expressed as mean \pm S.E.M. AOPP levels were expressed as nmol per liter of chloramin-T equivalent/mg protein. Data are statistically significant at ${ }^{*}, t, f, \# p<0.001$. (B) Variations of advanced oxidation protein products (AOPP) in albumin molecule exposed to metal catalyzed oxidation (MCO) with respect to incremental dihydrolipoic acid (DHLA) concentrations. Results are expressed as mean \pm S.E.M. AOPP levels were expressed as nmol per liter of chloramin-T equivalent/mg protein. Data are statistically significant at ${ }^{*}, t, f, \# p<0.001$.

intracellular functions ${ }^{31}$ Oxidative processes of the proteins have been widely reviewed by Stadmand and Levine. ${ }^{29}$

The oxidation of HSA results in an increase in PCO content. Both the POOH, PCO, and AOPP contents increased significantly with the time of incubation in our MCO assay system when compared with the levels in LA and DHLA applied samples. The current results showed a significant decrease in the level of free thiol groups when HSA was incubated in the absence of LA or DHLA. The antioxidant capacity of HSA against in vitro MCO in the absence of LA and DHLA is seen in Figure 2. When HSA was added to the oxidation mixture, it was observed that it slowed down the MCO reaction mildly in this time interval and compared in the same figure and the intersection point seen in the graph is probably where the reaction is ended and the antioxidant capacity of HSA is depleted. These findings indicate that HSA is highly oxidized at redox-active Cys 34 residue. As the LA and DHLA concentrations were increased from 25 to $100 \mu \mathrm{M}$, we observed two important points. High levels of HSA oxidation seemed to be decreased with 25 and $50 \mu \mathrm{M}$ concentrations gradually while P-SH groups increased. On the other hand at $75 \mu \mathrm{M}$
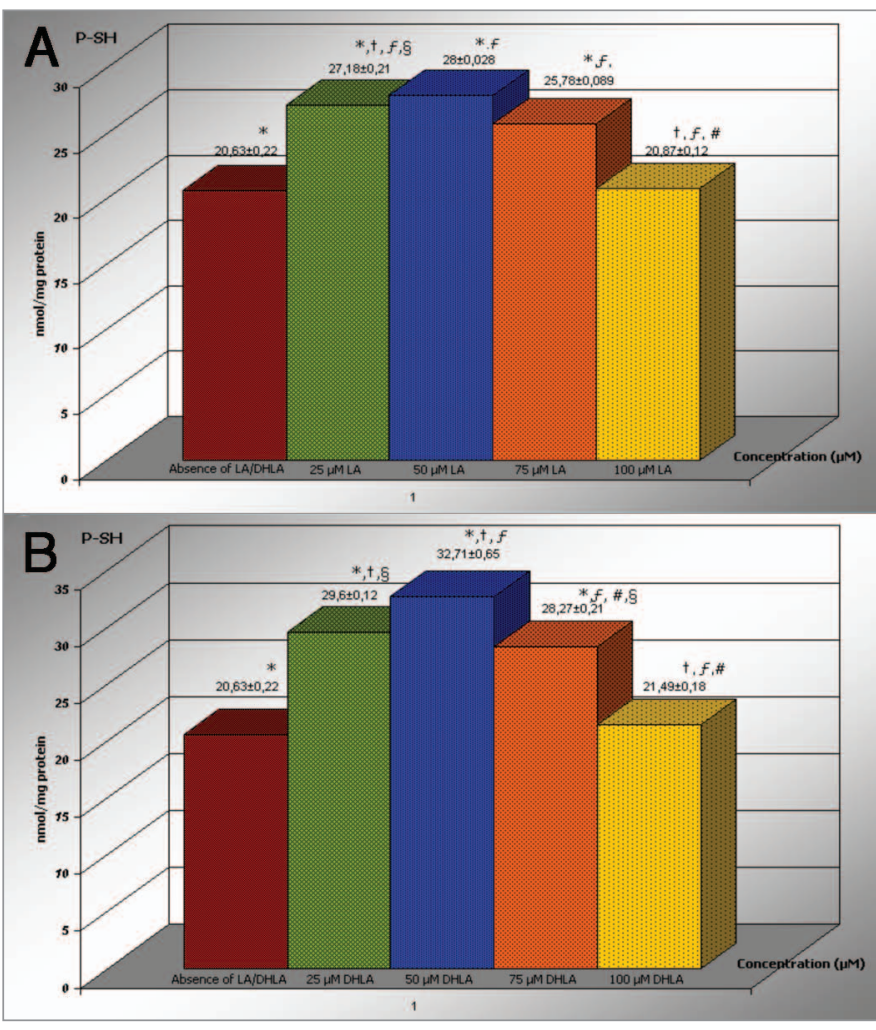

Figure 6. (A) Variations of protein thiol (P-SH) groups in albumin molecule exposed to metal catalyzed oxidation (MCO) with respect to incremental lipoic acid (LA) concentrations. Results are expressed as mean \pm S.E.M. P-SH levels are expressed as $\mathrm{nmol} / \mathrm{mg}$ protein. Data are statistically significant at ${ }^{*}, t, f, \# p<0.001$ and $\$ p<0.01$ respectively. (B) Variations of protein thiol (P-SH) groups in albumin molecule exposed to metal catalyzed oxidation (MCO) with respect to incremental dihydrolipoic acid (DHLA) concentrations. Results are expressed as mean \pm S.E.M. P-SH levels are expressed as $\mathrm{nmol} / \mathrm{mg}$ protein. Data are statistically significant at ${ }^{*}, t, f, \# p<0.001$ and $\S p<0.01$ respectively.

concentration of both LA and DHLA there was no additional improve on HSA oxidation and the MCO of HSA seemed to be increased as if there was no protection of these antioxidants with $100 \mu \mathrm{M}$ concentration. P-SH levels were amicable with these data. We can state that; $75 \mu \mathrm{M}$ has been the critical concentration value discriminating the antioxidant/prooxidant effects of LA and DHLA and with $100 \mu \mathrm{M}$ concentration the prooxidant effects of both LA and DHLA were seen. AOPP contain abundantly dityrosines which allow crosslinking, disulfide bridges and carbonyl groups. ${ }^{30}$ According to our current results; PCO and AOPP oxidation patterns seem to be compatible in respect to response to LA application. These data correspond to the recent findings $s^{20,30}$ indicating AOPP formation could happen to be partially from $\mathrm{PCO}$ reactions. According to our results, it was clearly seen that DHLA was more influential on MCO when compared with that of LA.

Suji et al. ${ }^{6}$ find that modification of bovine serum albumin by the physiological dicarbonyl compound methylglyoxal results in a new binding site for the ligand LA and probable reason for this altered binding characteristics seem to be conformational changes induced during LA binding. The relevant literature indicates that 
Table 1. The rationale for oxidative stress assays and outlines the experiments performed

\begin{tabular}{cc} 
Abbreviation & Parameters \\
PCO (nmol/mg protein) & Protein carbonyl groups \\
POOH (nmol/mg protein) & Protein hydroperoxide groups \\
\hline AOPP (nmol per liter of chloramin-T equivalent/mg protein) & Advanced oxidation protein products $\quad$ Heterogenous products of protein oxidation \\
\hline $\mathrm{P}-\mathrm{SH}$ (nmol/mg protein) & Protein thiol groups
\end{tabular}

$\mathrm{PCO}$, protein carbonyl groups; $\mathrm{P}-\mathrm{OOH}$, protein hydroperoxide groups; $\mathrm{AOPP}$, advanced oxidation protein products; $\mathrm{P}-\mathrm{SH}$, protein thiol groups

antioxidant/pro-oxidant effect of LA/DHLA depends on its dose. ${ }^{8,15,32}$ For example, in tumor cells, LA at low concentrations $(1 \mu \mathrm{mol} / \mathrm{L})$ increased cell proliferation rate, while LA at high concentrations $(100 \mu \mathrm{mol} / \mathrm{L})$ exhibited a distinct anti-proliferative effect. ${ }^{33}$ In addition, LA could act as a prooxidant at particular concentrations in chemical systems and living tissues. 8,14,15 The concentration range of LA and DHLA tested in our study is on the same level with the concentrations used in in vivo studies. ${ }^{34-37}$ In this respect our study partially clarifies for the in vivo redox status of HSA with LA and DHLA. Also, it can be said that thiol-based antioxidants may not only fail to alleviate ROS toxicity, but in certain circumstances, such as their redox status, concentration, and optically active form, ${ }^{8}$ even promote it.

Although redox homeostasis mechanisms are often studied in cellular systems, it is likely that the main benefits of redox-active agents such as LA and DHLA should be investigated by compromised systems where oxidative stress is intermittently high. In the present study, it was intended to form the model conditions of MCO on HSA that imitating the physiological conditions in vitro. We observed the probable effects of LA/DHLA redox couple on HSA oxidation depending on the concentration and redox status. We can say that uptake and recycling of antioxidants depends on the cell type or redox state of cellular/ extracellular environment, so with this experiment we could stabilize the conditions. We also provide the first demonstration that the HSA oxidation in MCO system was evidenced not only with protein carbonylation but also with $\mathrm{POOH}$, AOPP formation and loss of P-SH groups so this is the most new point of this study.

Considering LA being extensively investigated clinically and has been shown to be redox sensitive, it is capable of acting as a pro-oxidant and/or antioxidant in certain conditions. The oxidized (LA) and reduced (DHLA) forms create a potent redox couple that has a standard reduction potential of $-0.32 \mathrm{~V}$. This makes DHLA one of the most potent naturally occurring antioxidants. ${ }^{38}$ Iron is a redox active element, which can seriously exacerbate oxidative stres by generating $\mathrm{OH}$ radicals via Fenton chemistry. DHLA accelerated irondependent $\mathrm{OH}$ generation. Generation and lipid peroxidation, probably by reducing $\mathrm{Fe}^{+3}$ to $\mathrm{Fe}^{+2}$. LA inhibited this pro-oxidant action of DHLA. DHLA can also exert pro-oxidant properties, both by its iron ion-reducing ability (Fig. 1). ${ }^{15}$ In this study, LA, and especially DHLA, seem have the ability to prevent MCO and like LA, DHLA also chelates transition metal ions and in turn alleviates metal-catalyzed protein oxidation reactions in moderate doses. However, in high concentrations the converse effects of both exists. If LA exerts similar effects to those seen in the present study, it is possible that cellular prooxidant effect could result.

Oxidative stress is believed to play a pathophysiological role in different diseases ${ }^{39}$ and contributes to the pathophysiology of exposure to metals. It is readily conceivable that the ligand-binding properties of albumin may be altered during the development of these pathologies. Excessive levels of serum iron has been observed to be a risk factor for an increasing number and diversity of disease conditions. ${ }^{40}$ Age-related disorders influence the redox state of albumin and this influences the ligand-binding properties. LA and its reduced form DHLA are both capable of acting as antioxidants (Fig. 1). However, antioxidant performance of HSA has not been entirely clarified due to a lack of understanding of all these redox homeostasis mechanisms in human plasma. In our opinion: Human studies are limited in this regard. The administration of various natural or synthetic antioxidants has been shown to be of benefit in prevention and attenuation metal-induced oxidative alterations in human plasma. On the other hand, surprisingly, the antioxidant supplements may exhibit pro-oxidant properties and even worsen metal induced pro-oxidant damage. ${ }^{41}$

These findings will, we hope, lead to a new insight into the molecular pathogenesis of oxidized-HSA related human diseases such as atherosclerosis as oxidative stress is known to be a mediator. ${ }^{42}$ The mechanisms by which LA may confer protection in models of established atherosclerosis were studied and it was found that LA reduced the proliferation of atherosclerotic plaques in the abdominal aorta and improved intravascular reactivity. ${ }^{43}$ In a previous study, a protective activity of alpha-lipoic acid in hypercholesterolemic-induced animals was investigated in atherosclerosis model. It was suggested that LA posses a dual lipid lowering and anti-atherosclerotic properties indicated with low plasma triglyceride and low density lipoprotein levels and reduction of athero-lesion formation in hypercholesterolemic-induced rabbits. ${ }^{44}$ LA represents a potential agent on the vascular endothelium, recording to LA/DHLA redox couple is one of the most powerful biological antioxidant systems. ${ }^{45}$ The favorable antioxidant, anti-inflammatory, metabolic and endothelial effects of LA shown in rodents recently published studies ${ }^{46}$ warrant further assessment of its potential role for prevention and treatment of cardiovascular diseases. On the other hand inhibition of MCO in systemic circulation by LA/DHLA redox couple may be one of the possible therapeutic effects of thiol-based antioxidants, and thus the underlying molecular mechanism needs to be further clarifications. 


\section{Methods}

Materials. All reagents including recombinant HSA, racemic mixture of LA and DHLA were purchased from Sigma (St Louis, $\mathrm{MO})$. Albumin isolated from blood serum or plasma is usually heterogeneous. ${ }^{6}$ The heterogeneity is caused by some of the factors such as the variable extent of oxidation of the thiol group at Cys-34 (e.g., as a disulfide) and variations in the number and types of bound fatty acids ${ }^{6}$ In the present work, we have attempted to avoid this problem by carrying out experiments with recombinant HSA.

Metal catalyzed oxidation of recombinant human serum albumin. Recombinant HSA $(100 \mathrm{mg})$ was dissolved at a concentration of $10 \mathrm{mg} / \mathrm{mL}$ in the oxidation buffer $(50 \mathrm{mM}$ HEPES, $\mathrm{N}$-2-hydroxyethylpiperazine-N'-2-ethanesulfonic acid buffer, $\mathrm{pH}$ 7.4, containing $100 \mathrm{mM} \mathrm{KCl}$ and $10 \mathrm{~mm} \mathrm{MgCl}{ }_{2}$ ). The oxidation mixture was prepared by adding neutral ascorbic acid and $\mathrm{FeCl}_{3}$ to final concentrations of $25 \mathrm{mM}$ and $100 \mu \mathrm{M}$, respectively. ${ }^{47} \mathrm{To}$ initiate reducing the $\mathrm{Fe}^{3+}$ to $\mathrm{Fe}^{2+}$, ascorbic acid was added to the oxidation buffer. Ascorbat oxidation was monitored for $15 \mathrm{~min}$ by measuring the loss of absorbance at $265 \mathrm{~nm}$ in a Beckman DU-640 spectrophotometer. ${ }^{12}$ To test antioxidant effect of LA $(25,50,75,100 \mu \mathrm{M})$ and DHLA $(25,50,75,100 \mu \mathrm{M})$ as a function of concentration, each of them was added separately in the same buffer. The oxidation mixture was incubated for $72 \mathrm{~h}$ at $37^{\circ} \mathrm{C}$ in a shaking bath, after which oxidation procedure was terminated by addition of EDTA (ethylenediaminetetraacetic acid) to $1 \mathrm{mM} .{ }^{47}$ Control samples were prepared in oxidation buffer supplemented with $1 \mathrm{mM}$ EDTA.

Evaluation of protein oxidation extent. Assesment of of protein hydroperoxides (P-OOH) formation after LA/DHLA treatment and susceptibility to protein carbonyl (PCO) formation were performed according to Kayali et al. ${ }^{48}$ and Reznick et al. ${ }^{49}$ respectively. Advanced oxidation endproducts (AOPP) determination was carried out by the method of Witko-Sarsat. ${ }^{50}$ Protein thiol (P-SH) concentration was determined by using $5,5^{\prime}$-dithiobis(2-nitrobenzoic acid) (DTNB) as previously described by $\mathrm{Hu}{ }^{51}$ The rationale for oxidative stress assays and outlines the experiments performed were given in Table 1.

Assay of protein hydroperoxides. $\mathrm{P}-\mathrm{OOH}$ were measured by the guanidine-perchloric acid-ferric-xylenol orange method (G-PCA-FOX). ${ }^{48}$ The assay is based on the oxidation of $\mathrm{Fe}^{2+}$ by peroxides in the presence of the dye xylenol orange that gives a coloured complex with the $\mathrm{Fe}^{3+}$ generated. The Fe-XO complex can be measured in the visible absorbance range $(560 \mathrm{~nm})$. Proteins were precipitated from $100 \mu \mathrm{L}$ of sample by the addition of $500 \mu \mathrm{L}$ of $0.2 \mathrm{M}$ ice-cold perchloric acid. Samples were kept on ice for $5 \mathrm{~min}$ and centrifuged at $6500 \mathrm{~g}$. The precipitated proteins were dissolved in $1100 \mu \mathrm{L}$ of $6 \mathrm{M}$ guanidine hydrochloride. After mixing of the washed protein solution, xylenol orange, and ferrous solutions, the absorbance at $560 \mathrm{~nm}$ was read after $60 \mathrm{~min}$ against a blank containing $6 \mathrm{M}$ guanidine hydrochloride instead of the protein solution. The molar concentration of $\mathrm{P}-\mathrm{OOH}$ in the final medium was calculated with the Beer-Lambert equation by using the molar absorption coefficient value of 37,000 $\mathrm{M}^{-1} \mathrm{~cm}^{-1}$. The coefficients of intra- and inter-assay variations for $\mathrm{P}-\mathrm{OOH}$ assay were determined as 3.2\% $(\mathrm{n}=10)$ and $7.9 \%$ $(n=10)$, respectively.

Assay of protein carbonyl groups. PCO groups react with 2,4-dinitrophenylhydrazine (DNPH) to generate chromophoric dinitrophenylhydrazones. DNPH was dissolved in $\mathrm{HCl}$, and after the DNPH reaction, proteins were precipitated with an equal volume of $20 \%(\mathrm{w} / \mathrm{v})$ trichloroacetic acid and washed three times with $4 \mathrm{~mL}$ of an ethanol/ethyl acetate mixture (1:1). Washings were achieved by mechanical disruption of pellets in the washing solution using a small spatula, and re-pelleting by centrifugation at $6000 \mathrm{~g}$ for $5 \mathrm{~min}$. Finally, the protein precipitates were dissolved in $6 \mathrm{M}$-guanidine- $\mathrm{HCl}$ solution and the absorbances were measured at $360 \mathrm{~nm}$ wavelength using the molar extinction coefficient of DNPH, $2.2 \times 10^{4} \mathrm{M}^{-1} . \mathrm{cm}^{-1} .49$

Assay of advanced protein oxidation products. Samples were prepared in the following way: $200 \mu \mathrm{L}$ of sample was diluted 1:5 in phosphate-buffered saline. $10 \mu \mathrm{L}$ of $1.16 \mathrm{M}$ potassium iodide was then added to each tube, two minutes later followed by the $20 \mu \mathrm{L}$ acetic acid. The absorbance of the reaction mixture was immediately read at $340 \mathrm{~nm}$ against a blank containing $2000 \mu \mathrm{L}$ of phosphate buffered saline, $100 \mu \mathrm{L}$ of KI, and $200 \mu \mathrm{L}$ of acetic acid. ${ }^{50}$ The coefficients of intra- and inter-assay variations were determined as $1.5 \%(n=10)$ and $2.7 \%(n=10)$, respectively.

Assay of protein thiol groups. P-SH groups was determined by using 5,5'-dithio-bis(2-nitrobenzoic acid) (DTNB). ${ }^{51}$ The coefficients of intra- and inter-assay variations were $1.3 \%$ (n $=10)$ and $3.6 \%(\mathrm{n}=10)$, respectively.

Determination of protein concentrations. Since the conventional methods such as Bradford's method might not be suitable for determination of the oxidized protein concentration in the final solutions, protein determinations were checked by the UV absorption of proteins at $280 \mathrm{~nm}$.

Statistical analysis. The level of statistical significance was determined by ANOVA with Tukey's post-hoc test, using Instat statistical software. Results are expressed as mean \pm SEM of at least three independent experiments.

\section{Acknowledgements}

The authors want to express their gratitude to Ms. Karolin Yanar for her timely assistance.

\section{References}

1. Oetti K, Stauber RE. Physiological and pathological changes in the redox state of human serum albumin critically influence its binding properties. $\mathrm{Br} \mathrm{J}$ Pharmacol 2007; 151:580-90.

2. Çakatay U, Aydın S, Yanar K, Uzun H. Genderdependent variations in systemic biomarkers of protein, DNA, and lipid damage in aged rats. Aging Male 2010; 13:51-8.
3. Çakatay U, Kayalı R, Uzun H. Relation of protein oxidation parameters and paraoxonase activity in the ageing population. Clin Exp Med 2008; 8:51-7.

4. Roche M, Rondeau P, Singh NR, Tarnus E, Bourdon E. The antioxidant properties of serum albumin. FEBS Lett 2008; 582:1783-7.

5. Kawakami A, Kubota K, Yamada N, Tagami U, Takehana K, Sonaka I, et al. Identification and characterization of oxidized human serum albumin, FEBS Journal 2006; 273:3346-57.
6. Stewart AJ, Blindauer CA, Berezenko S, Sleep D, Sadler PJ. Interdomain zinc site on human albumin. Proc Natl Acad Sci USA 2003; 100:3701-6.

7. Suji G, Khedkar SA, Singh SK, Kishore N, Coutinho $\mathrm{EC}$, Bhor VM, et al. Binding of lipoic acid induces conformational change and appearance of a new binding site in methylglyoxal modified serum albumin. Protein J 2008; 27:205-14. 
8. Çakatay U. Should it be safer to use a redox couple, both with (R)-alpha-lipoic acid combined with (R)-dihydrolipoic acid for avoiding prooxidant action of alpha-lipoic acid? Med Hypotheses 2007; 68:1178.

9. Bast A, Haenen GR. Lipoic acid: a multifunctional antioxidant. Biofactors 2003; 17:207-13.

10. Kayalı R, Çakatay U, Kızıler AR, Aydemir B. Effect of alpha-lipoic acid supplementation on trace element levels in serum and in postmitotic tissue in aged rats. Med Chem 2007; 3:297-300.

11. Cakatay U, Kayali R, Kızıler AR, Aydemir B. Postmitotic tissue selenium and manganese levels in alpha-lipoic acid-supplemented aged rats. Chem Biol Interact 2008; 171:306-11.

12. Suh JZ, Zhu BZ, Szoeke E, Frei B, Hagen TM. Dihydrolipoic acid lowers the redox activity of transition metal ions but does not remove them from the active site of enzymes. Redox Rep 2004; 9:57-61.

13. Lodge JK, Traber MG, Packer L. Thiol chelation of Cu $2+$ by dihydrolipoic acid prevents human low density lipoprotein peroxidation. Free Radic Biol Med 1998; 25:287-97.

14. Çakatay U, Kayalı R, Sivas A, Tekeli F. Prooxidant activities of alpha-lipoic acid on oxidative protein damage in the aging rat heart muscle. Arch Gerontol Geriatr 2005; 40:231-40.

15. Çakatay U. Pro-oxidant actions of alpha-lipoic acid and dihydrolipoic acid. Med Hypotheses 2006; 66:110-7.

16. Roche M, Rondeau P, Singh NR, Tarnus E, Bourdon E. The antioxidant properties of serum albumin. FEBS Letters 2008; 582:1783-7.

17. Carter DC, Ho JX. Structure of serum albumin. Ady Protein Chem 1994; 45: 153-203.

18. Lissi E, Biasutti MA, Abuin E, Leon L. A fluorescence study of human serum albumin binding sites modification by hypochlorite. J of Photochem and Photobiol B: Biology 2009; 94:77-81.

19. Baron CP, Refsgaard HH, Skibsted LH, Andersen ML. Oxidation of bovine serum albumin initiated by the Fenton reaction-effect of EDTA, tert-butylhydroperoxide and tetrahydrofuran. Free Radic Res 2006; 40:409-17.

20. Iwao Y, Anraku M, Hiraike M, Kawai K, Nakajou $\mathrm{K}$, Kai $\mathrm{T}$, et al. The structural and pharmacokinetic properties of oxidised human serum albumin, advanced oxidation protein products (AOPP). Drug Metab Pharmacokinet 2006; 21:140-6.

21. Temple A, Yen TY, Gronet S. Identification of Specific Protein Carbonylation Sites in Model Oxidations of Human Serum Albumin. J Am Soc Mass Spectrom 2006; 17:1172-80.
22. Suji G, Sivakami S. Malondialdehyde, a lipid-derived aldehyde alters the reactivity of Cys34 and the esterase activity of serum albumin. Toxicol in Vitro 2008; 22:618-24.

23. Meuccis E, Mordente A, Martorana GE. Metal-catalyzed oxidation of human serum albumin: Conformational and functional changes. Impl In Protein Aging 1991; 266:4692-9.

24. Kragh-Hansen U. Molecular aspects of ligand binding to serum albumin. Pharmacol Rev 1981; 33:17-53.

25. Peters T. Serum albumin. Adv Protein Chem 1985; 37:161-245.

26. Sadler PJ, Tucker A, JViles JH. Involvement of a lysine residue in the $\mathrm{N}$-terminal $\mathrm{Ni} 2$ _ and $\mathrm{Cu} 2$ _ binding-site of serum albumins, Comparison with $\mathrm{Co} 2, \mathrm{Cd} 2$, and Al2_. Eur J Biochem 1994; 220:193.

27. Jana CK, Das N, Sohal RS. Specificity of age-related carbonylation of plasma proteins in the mouse and rat. Arch Biochem Biophys 2002; 397:433.

28. Loban A, Kime R, Powers H.Iron-binding antioxidant potential of plasma albumin. Clin Sci 1997; 93:445-51.

29. Stadtman ER, Levine RL. Chemical modification of proteins by reactive species. In: Dalle-Donne I, Scaloni A, Butterfield DA (Eds.), Redox Proteomics. WileyInterscience, New Jersey 2006; Ch. 1.

30. Capéillere-Blandin C, Gausson V, Descamps-Latscha B, Witko-Sarsat V. Biochemical and spectrophotometric significance of advanced oxidized protein products. Biochim Biophys Acta 2004; 1689:91-102.

31. Jones DP. Extracellular redox state: refining the definition of oxidative stress in aging. Rejuv Res 2006; 9:169-81.

32. Bilska A, Wlodek L. Lipoic acid-the drug of the future? Pharmacol Rep 2005; 57:570-7.

33. Dovinova I, Novotny L, P. Rauko, P. Kvasnicka, Combined effect of lipoic acid and doxorubicin in murine leukemia. Neoplasma 1999; 46:237-41.

34. Amenta F, Traini E, Tomassoni D, Mignini F. Pharmacokinetics of different formulations of thioctic (alpha-lipoic) acid in healthy volunteers. Clinical and Exp Hypertension 2008; 30:767-75

35. Kim HY, Oi Y, Kim M, Yokozawa T. Protective effect of lipoic acid against methyl glyoxal induced oxidative stress in LLC-PK1 cells. J Nutr Sci Vitaminol 2008; 54:99-104

36. Coleman MD, Eason RC, Bailey CJ. The therapeutic use of lipoic acid in diabetes: a current perspective. Environ Toxicol and Pharm 2001; 10:167-72.
37. Maczurek A, Hager K, Kenklies M, Sharman M Martins R, Engel J, et al. Lipoic acid as an anti-inflammatory and neuroprotective treatment for Alzheimer's Disease. Advanced Drug Delivery Reviews 2008; 60:1463-70.

38. Searls RL, Sanadi DR. Alpha-Ketoglutaric dehydrogenase. 8. Isolation and some properties of a flavoprotein component. J Biol Chem 1960; 235:2485-91.

39. Halliwell B, Gutteridge JMC. Free Radicals in Biology and Medicine. Oxford University Press: New York, 1999.

40. Weinberg ED. Iron toxicity: New conditions continue to emerge. Oxid Med Cell Longev 2009; 2:107-9.

41. Flora SJS. Structural, chemical and biological aspects of antioxidants for strategies against metal and metalloid exposure. Oxid Med Cell Longev 2009; 2:191-206.

42. Elahi MM, Kong YX, Matata BM. Oxidative stress as a mediator of cardiovascular disease. Oxid Med Cell Longev 2009; 2:259-69.

43. Ying Z, Kherada N, Farrar B, Kampfrath T, Chung Y, Simonetti $\mathrm{O}$, et al. Lipoic acid effects on established atherosclerosis. Life Sci 2010; 86:95-102.

44. Amom Z, Zakaria Z, Mohamed J, Azlan A, Bahari H, Taufik Hidayat Baharuldin M, et al. Lipid lowering effect of antioxidant alpha-lipoic Acid in experimental atherosclerosis. J Clin Biochem Nutr 2008; 43:88-94.

45. Ghibu S, Richard C, Delemasure S, Vergely C, Mogosan C, Muresan A. An endogenous dithiol with antioxidant properties: alpha-lipoic acid, potential use in cardiovascular diseases. Ann Cardiol Angeiol 2008; 57:161-5.

46. Tardif JC, Rhéaume E. Lipoic acid supplementation and endothelial function. Br J Pharmacol 2008;153:1587-8.

47. Temple A, Yen TY, Gronert S. Identification of specific protein carbonylation sites in model oxidations of human serum albumin. J Am Soc Mass Spectrom 2006; 17:1172-80.

48. Kayali U, Cakatay U, Tekeli F. Male rats exhibit highe oxidative protein damage than females of the same chronological age. Mech Ageing Dev 2007; 128:365-9.

49. Reznick AZ, Packer L. Oxidative damage to proteins: spectrophotometric method for carbonyl assay. Methods Enzymol 1994; 233:357-63.

50. Witko V, Nguyen AT, Descamps-Latscha B. Microtiter plate assay for phagocyte derivered taurine-chloramines. J Clin Lab Anal 1992; 6:47-53.

51. Hu ML. Measurement of protein thiol groups and glutathione in plasma. Methods Enzymol 1994; 233:381-5. 


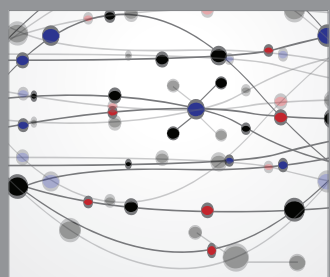

The Scientific World Journal
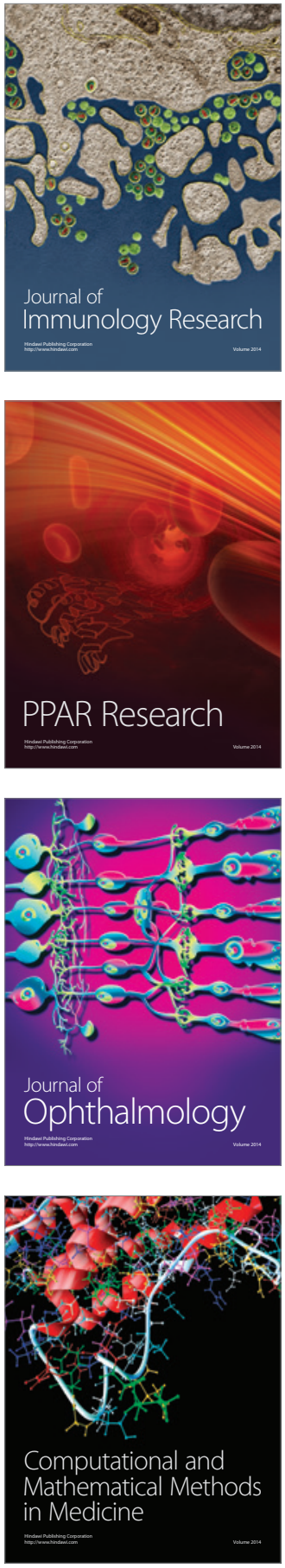

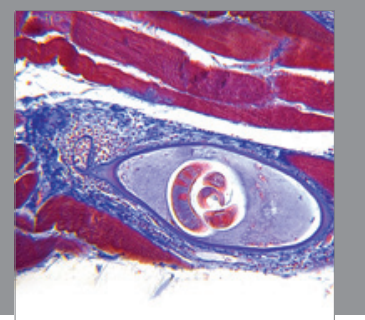

Gastroenterology

Research and Practice
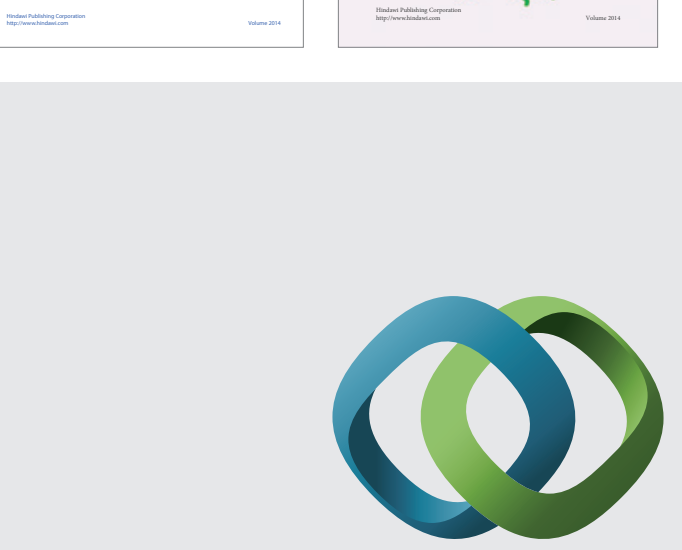

\section{Hindawi}

Submit your manuscripts at

http://www.hindawi.com
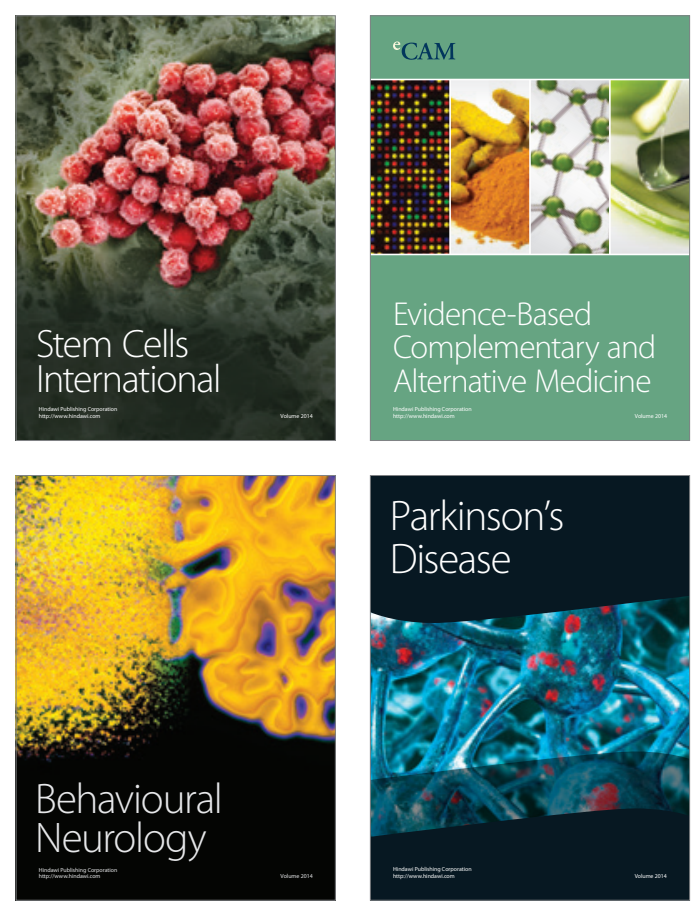

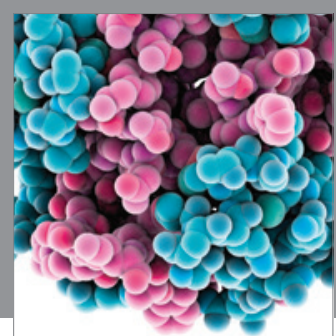

Journal of
Diabetes Research

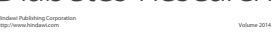

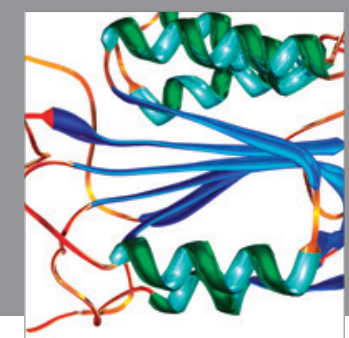

Disease Markers
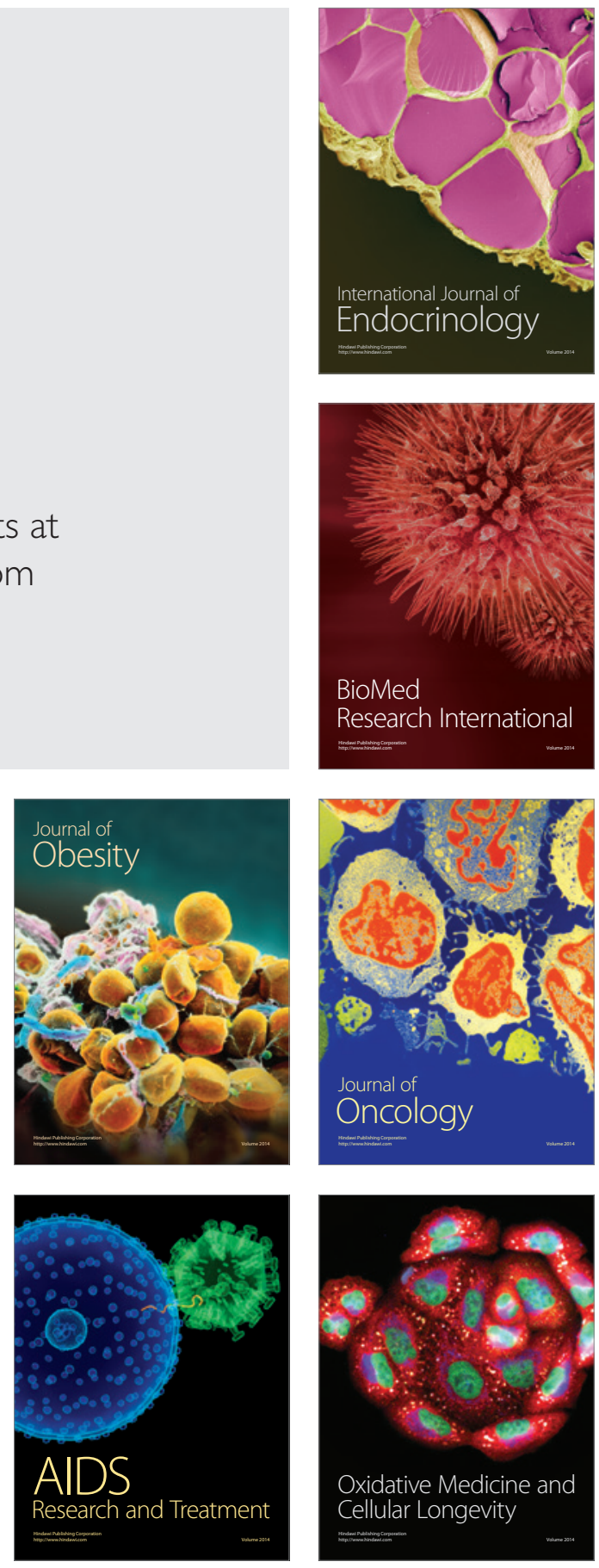